\title{
Does Living in Previously Exposed Malaria or Warm Areas is Associated with a Lower Risk of Severe COVID- 19 Infection in Italy?
} \author{
Orrù ${ }^{2,4, *(D)}$

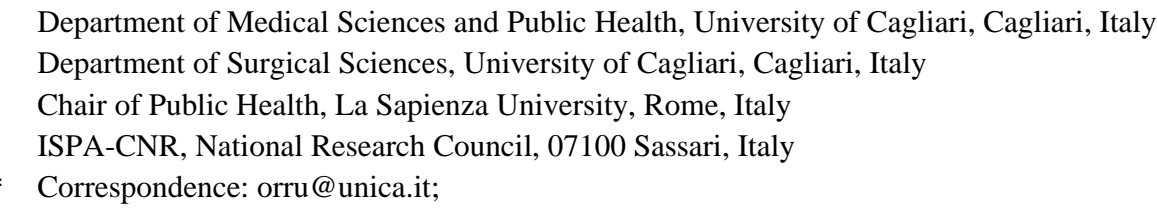

Mauro Giovanni Carta ${ }^{1(\mathbb{D})}$, Alessandra Scano ${ }^{2}{ }^{(\mathbb{C})}$, Luigi Minerba ${ }^{1(\mathbb{C})}$ Ferdinando Romano $^{3(\mathbb{C}}$, Germano

Scopus Author ID 6603502746

Received: 10.08.2020; Revised: 10.09.2020; Accepted: 14.09.2020; Published: 16.09.2020

\begin{abstract}
Incidence of Covid-19 positivity (21/2/2020-28/3/2020) in provinces of 4 Italian regions whose territory was described as previously exposed to Malaria was compared with those of other provinces of the same regions. The climate of such provinces was compared with the climate of the other provinces in some regions. Previously malarial areas show a lower risk than other provinces of the same regions: Mantua (Lombardy) RR=0.94 (CI95\%0.89-0.99); Venice-Rovigo (Veneto) RR=0.61 (CI95\%0.58-0.65); Ferrara-Ravenna (Emilia-Romagna) RR=0.37 (CI95\%0.35-0.41); CagliariOristano-SouthSardinia (Sardinia) RR=0.25 (0.17-0.31). The maximum temperature in March 2020 in those provinces was higher in mean $1.5^{\circ}$ for other provinces. The lower frequency of COVID-19 in the provinces previously exposed to Malaria of four Italian regions does not reveal a causal link. The phenomenon has emerged independently in all the regions investigated. People born between the 1920s and 1950s were those most exposed to malaria years ago and today are the most exposed to the severest forms of COVID-19. A warmer climate seems to be associated with a lower risk of COVID, in line with the evidence highlighted in equatorial states where a lower lethality of the virus has emerged, however this regardless of the presence of Malaria. This may suggest that climate and not Malaria is the real risk factor, though further studies need to determine the role of the association climate / COVID.
\end{abstract}

Keywords: Malaria; COVID-19; infections; weather.

(C) 2020 by the authors. This article is an open-access article distributed under the terms and conditions of the Creative Commons Attribution (CC BY) license (https://creativecommons.org/licenses/by/4.0/).

\section{Introduction}

In recent months, various biological-chemical and physical factors have been investigated as they potentially favor or contrast the progression of the Covid-19 pandemic [14]. This, often unduly amplified by the media, has generated folkloristic hypotheses and pseudo-preventive behaviors not always dictated by evidence. In Italy, some newspaper reports have advanced the hypothesis that areas exposed to Malaria in the past presented greater resilience to the epidemic. This was suggested by the appearance that the province of Ferrara, flagellated for centuries by the malarial epidemic until the 1960s, shows positivity rates for COVID-19 far lower than in the rest of the Emilia Romagna region. Experts interviewed and some preliminary reports about the geographical association between malaria and low risk for COVID [5] suggest: 1) that the situation should be confirmed in other areas, but 2) that even 
the micro-climate may be the real cause of such an association [5,6]. The purpose of this preliminary investigation was to verify whether the anecdotal observation of the postulated condition of protection of malarial areas in the Emilia-Romagna region might be confirmed by an epidemiological comparison and to see if it can be extended to other Italian regions. This research, therefore, aims to respond to the first of the two requests raised by the experts (i.e., to confirm the observation in other areas and, at the same time, to quantify the protective factor). However, as the heat has also recently been called into question as a possible protective factor [6], we have verified whether the same provinces have not had a warmer climate in the midst of the pandemic.

\section{Materials and Methods}

To verify our hypothesis, we found the Italian regions in which at least one province was totally described as at risk of Malaria on the mapping of malarial areas in 1882 [5]. We then compared the positivity rate of COVID-19 from 2 February 2020 to 28 March 2020 in those provinces whose territory was totally described as at risk of Malaria with the rate in the other provinces of the same region. This methodology was adopted because health care in Italy is organized on a regional basis. Therefore, provinces of the same region have the same level of quality of care, and people in the provinces of a region are equally likely to be identified as positive to the virus if infected. Moreover, official data on the current epidemic are available on a provincial basis. The fact that in the same region, other provinces were only partially considered malarial is a potential factor of bias but totally in favor of the null hypothesis. We have verified whether the same provinces have had a warmer climate (as maximum temperature) in the midst of the pandemic (march 2020) comparing the data produced by each ARPA (Regional Agency for Environmental Protection).

\section{Results and Discussion}

The 4 regions found with at least a whole province totally at risk for the previous Malaria were: Lombardy (province of Mantua with the previous risk of Malaria); Veneto (Rovigo and Venice with the previous risk of Malaria); Emilia Romagna (Ferrara and Ravenna with the previous risk of Malaria), Sardinia (Cagliari, South Sardinia and Oristano with the previous risk of Malaria). Table 1 shows the protective factor of living in post-malaria areas calculated as Risk Ratios. People living in previous malaria areas show a lower risk than people living in other provinces of the same regions: Mantua (Lombardy) $\mathrm{RR}=0.94$ (Confidence Interval [CI] 95\% 0.89-0.99); Venice and Rovigo (Veneto) $\mathrm{RR}=0.61$ (CI95\% 0.58-0.65); Ferrara and Ravenna (Emilia-Romagna) RR=0.37 (CI95\% 0.35-0.41); Cagliari, Oristano and South Sardinia (Sardinia) $R R=0.25$ (CI95\% 0.17-0.31). Table 2 showed that the same provinces had had a warmer climate (as the maximum temperature around 1.5 Celsius degree or more) of the other provinces of the same regions in the midst of the pandemic (March 2020). The study shows a lower frequency of COVID-19 positivity in people living in the provinces of four Italian regions that presented a high risk of Malaria at the end of the 19th century in comparison to the inhabitants of the provinces of the same regions that presented a lower risk of Malaria (in the whole province or in most part of it). Although our study is absolutely preliminary and limited in size, two aspects of strength must be underlined and warn us not to neglect the results: 1) the Italian organization against the COVID-19, as well as the entire Italian national health system, has been managed autonomously at the regional level and 
therefore the quality of services and type of response to the epidemic has been homogeneous in the different provinces compared in the same regions $[7,8] ; 2)$ the epidemic wave reached the different Italian regions at similar times. At the time of the evaluation, the provinces compared were, therefore, in the same phase of development of the epidemic and in the exact same period of the year. The average age of the Italian population and the distribution by gender are very stable by region; there is no significant deviation by provinces, so these risk factors are also highly balanced, although the data about positives at virus by gender and age are not available. The evidence of an association between living in provinces previously exposed to Malaria and the low risk of COVID-19, even if confirmed, does not clarify whether this is due to previous exposure to Malaria or if it depends on whether the previous malaria exposure coincides with a hot climate and exposure to Malaria is only a confounding factor. In this way, the hypotheses that "molecular and genetic variations associated with malaria might play a protective role against coronavirus infection" 3) should be prudentially evaluated before clarifying the existence of an actual causal link between Malaria and COVID protection. The association emerged independently in all four regions investigated, and thus the phenomenon may be of interest and needs to be investigated in depth. People born between the 1920s and 1950s, who are now 70-90 years of age, were the most exposed to Malaria and today, as elderly people, to the most severe forms of COVID-19. Therefore they should represent a not inconsiderable percentage of the "positives" surveyed in the various regions of one of the nations with the world's oldest population. We must consider that owing to the lack of diagnostic tests during the first phase of the epidemic in Italy (the first case in Italy was reported on 21 February 2020), the diagnostic tests were conducted only on highly suspect individuals. Therefore, it is very likely that many cases with mild symptoms have gone unnoticed [7-15]. The number of tests was, however, balanced by region (i.e., different regions did not have the same resources and tests but were homogeneous in the same region). A recent study by our group found that in temperate zones, COVID-19 has a higher lethality than in countries around the Equator [6, 16-20]. This result also appears to be independent of factors such as the younger age of the equatorial populations because it also occurs in states like Singapore, where the average age is higher than in the United States [6]. However, lower lethality data was confirmed in "warm" areas in which Malaria was not endemic as French Polynesia and New Caledonia. On the other hand, the low frequency of cases was confirmed in very hot Italian regions such as Sicily or Calabria, where most of the provinces simultaneously presented areas that had been exposed to Malaria and areas without malarial exposure. This date seems, therefore, to suggest that it would be the heat and not previous malarial endemic to determine the protective factor.

Table 1. Protective factor of living in post-malarial areas calculated as Risk Ratios.

\begin{tabular}{|c|c|c|c|c|c|c|}
\hline Region /Malaria yes no & $\begin{array}{lr}\text { Cases (positives at } \\
\text { screening } & \text { for } \\
\text { COVID-19) } & \text { from } \\
21 / 2 / 2019 & \text { to } \\
28 / 3 / 2020 & \\
\end{array}$ & $\begin{array}{l}\text { Incidence X } 100 \\
000 \text { of COVID-19 } \\
\text { from } 21 / 2 / 2019 \text { to } \\
28 / 3 / 2020\end{array}$ & $\begin{array}{l}\text { Chi } \\
\text { square }\end{array}$ & Sign & $\mathbf{R R}$ & $95 \% \mathrm{CI}$ \\
\hline Lombardy No Malaria & 36.782 & 380.9 & 4.577 & 0.032 & 0.94 & $0.89-0.99$ \\
\hline Lombardy Malaria (Mantua) & 1.484 & 359.9 & & & & \\
\hline Emilia Romagna No Malaria & 11.581 & 287.8 & 761.53 & $<0.0001$ & 0.37 & $0.35-0.41$ \\
\hline Emilia Romagna Malaria & 802 & 109.1 & & & & \\
\hline Veneto No Malaria & 6.525 & 170.9 & 236.32 & $<0.0001$ & 0.61 & $0.58-065$ \\
\hline Veneto Malaria (Rovigo Venice) & 1.141 & 104.8 & & & & \\
\hline Sardinia no Malaria & 463 & 66.1 & 259.92 & $<0.0001$ & 0.25 & $0.17-0.31$ \\
\hline Sardinia Malaria & 161 & 17.1 & & & & \\
\hline
\end{tabular}


Table 2. The maximum temperature on March 2020.

\begin{tabular}{l|l} 
Region & Maximum temperature \\
\hline Mantua & $12.7^{\circ}$ \\
\hline Lombardy without Mantua (11 provinces) & $10.9^{\circ}$ \\
\hline $\begin{array}{l}\text { Ferrara } \\
\text { Ravenna }\end{array}$ & $13.2^{\circ}$ \\
\hline Emilia Romagna without Ferrara and Ravenna (7 provinces) & $11.6^{\circ}$ \\
\hline $\begin{array}{l}\text { Rovigo } \\
\text { Venice }\end{array}$ & $13.1^{\circ}$ \\
\hline Veneto without Rovigo and Venice (5 provinces) & $10.9^{\circ}$ \\
\hline $\begin{array}{l}\text { Cagliari, } \\
\text { Oristano, } \\
\text { South Sardinia }\end{array}$ & $15.2^{\circ}$ \\
\hline $\begin{array}{l}\text { Sassari, } \\
\text { Nuoro }\end{array}$ & $13.9^{\circ}$ \\
Friedman test for repeated measured (for 8 provinces previously exposed to malaria) X2 $=8(1, \mathrm{~N}=8), \mathrm{p}=0.00468$.
\end{tabular}

\section{Conclusions}

This preliminary study shows a lower frequency of COVID-19 positivity in people living in the provinces of four Italian regions that presented a high risk of Malaria. This evidence does not point to a causal link. However, the phenomenon may be of interest and needs to be investigated since the association emerged independently in all four regions investigated. A warmer climate in the same provinces seems to be associated with a lower risk of COVID, in line with the evidence highlighted in equatorial states where a lower lethality of the virus has emerged. However this regardless of the presence of Malaria. This may suggest that climate and not Malaria is the real risk factor. Future studies need to determine the role of the association climate / COVID and verify if the association with areas previously exposed to Malaria is only a confounding factor.

\section{Funding}

This research received no external funding.

\section{Acknowledgments}

This research has no acknowledgment.

\section{Conflicts of Interest}

The authors declare that the research was conducted in the absence of any commercial or financial relationships that could be construed as a potential conflict of interest.

\section{References}

1. Lin, S.; Wei, D.; Sun, Y.; Chen, K.; Yang, L.; Liu, B.; Huang, Q.; Paoliello, M.M.B.; Li, H.; Wu, S. Regionspecific air pollutants and meteorological parameters influence COVID-19: A study from mainland China. Ecotoxicology and Environmental Safety 2020, 204, https://doi.org/10.1016/j.ecoenv.2020.111035.

2. Smit, A.J.; Fitchett, J.M.; Engelbrecht, F.A.; Scholes, R.J.; Dzhivhuho, G.; Sweijd, N.A. Winter Is Coming: A Southern Hemisphere Perspective of the Environmental Drivers of SARS-CoV-2 and the Potential Seasonality of COVID-19. International Journal of Environmental Research and Public Health 2020, 17, https://doi.org/10.3390/ijerph17165634.

3. Filippini, T.; Rothman, K.J.; Goffi, A.; Ferrari, F.; Maffeis, G.; Orsini, N.; Vinceti, M. Satellite-detected tropospheric nitrogen dioxide and spread of SARS-CoV-2 infection in Northern Italy. Science of The Total Environment 2020, 739, https://doi.org/10.1016/j.scitotenv.2020.140278.

4. Lu, Y.; Sun, K.; Guo, S.; Wang, J.; Li, A.; Rong, X.; Wang, T.; Shang, Y.; Chang, W.; Wang, S. Early Warning Indicators of Severe COVID-19: A Single-Center Study of Cases From Shanghai, China. Front Med. 2020, 7, https://doi.org/10.3389/fmed.2020.00432. 
5. Napoli, P.E.; Nioi, M. Global Spread of Coronavirus Disease 2019 and Malaria: An Epidemiological Paradox in the Early Stage of A Pandemic. Journal of Clinical Medicine 2020, 9, https://doi.org/10.3390/jcm9041138.

6. Carta, M.; Scano, A.; Lindert, J.; Bonanno, S.; Rinaldi, L.; Fais, S.; Orrù, G.J.E.r.f.m.; sciences, p. Association between the spread of COVID-19 and weather-climatic parameters. European Review for Medical and Pharmacological Sciences 2020, 24, 8226-8231, https://doi.org/10.26355/eurrev_202008_22512.

7. Carta, M.G.; Romano, F.; Orrù, G. The True Challenges of the Covid-19 Epidemics: The Need for Essential Levels of Care for All. The Open Respiratory Medicine Journal 2020, 14, 8-9, https://doi.org/10.2174/1874306402014010008.

8. Carta, M.; Orrù, G.; Scano, A.; Coghe, F.; Nunnari, G.; Facchini, G.; Numis, F.; Berretta, M. In the face of the SARS-CoV-2 outbreak, do people suffering from oncological disease need specific attention? European Review for Medical and Pharmacological Sciences 2020, 24, 3434-3436, https://doi.org/10.26355/eurrev_202004_20794.

9. Chiodini, J. COVID-19 and the impact on Malaria. Travel Medicine and Infectious Disease 2020, 35, https://doi.org/10.1016/j.tmaid.2020.101758.

10. Amimo, F.; Lambert, B.; Magit, A. What does the COVID-19 pandemic mean for HIV, tuberculosis, and malaria control? Tropical Medicine and Health 2020, 48, 1-4, https://doi.org/10.1186/s41182-020-00219-6.

11. Chanda-Kapata, P.; Kapata, N.; Zumla, A. COVID-19 and Malaria: A symptom screening challenge for malaria endemic countries. International Journal of Infectious Diseases 2020, 94, 151-153, https://doi.org/10.1016/j.ijid.2020.04.007.

12. Wang, J.; Xu, C.; Wong, Y.K.; He, Y.; Adegnika, A.A.; Kremsner, P.G.; Agnandji, S.T.; Sall, A.A.; Liang, Z.; Qiu, C.; Liao, F.L.; Jiang, T.; Krishna, S.; Tu, Y. Preparedness is essential for malaria-endemic regions during the COVID-19 pandemic. The Lancet 2020, 395, 1094-1096, https://doi.org/10.1016/S01406736(20)30561-4.

13. González-Montero J, Valenzuela G, Ahumada M, Barajas O, Villanueva L. Management of cancer patients during COVID-19 pandemic at developing countries. World J Clin Cases. 2020, 8,3390-3404. doi:10.12998/wjcc.v8.i16.3390.

14. Krishan K, Kanchan T. Novel Coronavirus (SARS-CoV-2) resistance in African populations: A cause worth exploring. Acta Biomed. 2020, 91, e2020023, doi:10.23750/abm.v91i3.9872.

15. Sargin, G.; Yavaşoğlu, S.İ; Yavasoglu, I. Is Coronavirus Disease 2019 (COVID-19) seen less in countries more exposed to Malaria? Medical Hypotheses 2020, 140, https://doi.org/10.1016/j.mehy.2020.109756.

16. Setti, L.; Passarini, F.; De Gennaro, G.; Barbieri, P.; Pallavicini, A.; Ruscio, M.; Piscitelli, P.; Colao, A.; Miani, A. Searching for SARS-COV-2 on Particulate Matter: A Possible Early Indicator of COVID-19 Epidemic Recurrence. International Journal of Environmental Research and Public Health 2020, 17, https://doi.org/10.3390/ijerph17092986.

17. Prata, D.N.; Rodrigues, W.; Bermejo, P.H. Temperature significantly changes COVID-19 transmission in (sub)tropical cities of Brazil. Science of The Total Environment 2020, 729, https://doi.org/10.1016/j.scitotenv.2020.138862.

18. Meo, S.; Abukhalaf, A.; Alomar, A.; Al-Beeshi, I.; Alhowikan, A.; Shafi, K.; Meo, A.; Usmani, A.; Akram, J.J.E.r.f.m.; sciences, p. Climate and COVID-19 pandemic: effect of heat and humidity on the incidence and mortality in world's top ten hottest and top ten coldest countries. 2020, 24, 8232-8238, https://doi.org/10.26355/eurrev_202008_22513.

19. Hozhabri, H.; Piceci Sparascio, F.; Sohrabi, H.; Mousavifar, L.; Roy, R.; Scribano, D.; De Luca, A.; Ambrosi, C.; Sarshar, M. The Global Emergency of Novel Coronavirus (SARS-CoV-2): An Update of the Current Status and Forecasting. International Journal of Environmental Research and Public Health 2020, 17, https://doi.org/10.3390/ijerph17165648.

20. Kodera, S.; Rashed, E.A.; Hirata, A. Correlation between COVID-19 Morbidity and Mortality Rates in Japan and Local Population Density, Temperature, and Absolute Humidity. International Journal of Environmental Research and Public Health 2020, 17, https://doi.org/10.3390/ijerph17155477. 